\title{
Emotional intelligence of police
}

\author{
DANESHWARI ONKARI AND SUNANDA ITAGI
}

Received: 18.01.2017; Revised: 19.03.2017; Accepted: 05.04.2017

See end of the paper for authors' affiliations

\section{SUNANDA ITAGI}

Department of Human Development and

Family Studies, College of Rural Home

Science, University of Agricultural

Sciences, DHARWAD (KARNATAKA)

INDIA

Email : itagi.sk@gmail.com
ABSTRACT : A study on emotional intelligence of police was carried out in the year 2014-15 in Dharwad taluk with the objectives to assess the emotional intelligence of police and to know the relation between selected demographic variables with emotional intelligence of police. A total of 120 police were randomly selected from 22 police stations of Dharwad taluk. Emotional intelligence was assessed using emotional intelligence questionnaire (EQi) developed by Dulewicz and Higgs (2001), socio-economic status was assessed using socio-economic status scale developed by Aggarwal et al. (2005) and self structured questionnaire was used to elicit information regarding personal and work background. The data was collected through questionnaire method along with personal interview of the respondents. The results revealed that 50 per cent police had average level of emotional intelligence followed by low and high level (45.8\% and $4.2 \%$, respectively). Majority (56.67\%) of women had average level of emotional intelligence while 41.67 per cent had low and only 1.67 were in high level whereas majority (50\%) of men had low level of emotional intelligence while 43.3 per cent were in average and 6.67 per cent had high level. Majority (56.67\%) of rural police had average level of emotional intelligence while 43.33 per cent had low and none were in high level whereas majority (48.33\%) of urban police had average level of emotional intelligence while 43.3 per cent were in low level and 8.33 per cent had high level Emotional intelligence had significant and positive relationship with work experience, distance between residence and work place highlighting that higher the work experience and larger the distance from residence to work place increases emotional intelligence.

KEY WORDS: Emotional intelligence, Consciousness, Influence, Self awareness

- HOW TO CITE THIS PAPER : Onkari, Daneshwari and Itagi, Sunanda (2017). Emotional intelligence of police. Asian J. Home Sci., 12 (1) : 25-33, DOI: 10.15740/HAS/AJHS/12.1/25-33. 